\title{
The Relationship between Emotional Intelligence and Well-Being in Academic Employees
}

\author{
Phillip Bowen ${ }^{1}$, Andrew Pilkington ${ }^{2} \&$ Richard Rose $^{2}$ \\ ${ }^{1}$ Northampton Business School, University of Northampton, UK \\ ${ }^{2}$ School of Education, University of Northampton, UK \\ Correspondence Phillip Bowen, Northampton Business School, University of Northampton, Park Campus, Boughton \\ Green Road, Northampton, NN2 7AL, UK
}

Received: February 22, 2016

Accepted: March 17, 2016

Available online: March 22, 2016

doi:10.11114/ijsss.v4i5.1487

URL: http://dx.doi.org/10.11114/ijsss.v4i5.1487

\begin{abstract}
The aim of this study is to investigate the relationships between emotional demands, emotional intelligence and perceived stress in a sample of academic employees. The sample size of $100 \%(\mathrm{~N}=533)$ includes the following: $45.8 \%$ $(\mathrm{N}=244)$ are male with a mean age of $48.78(\mathrm{SD}=10.9)$ and median of 49 ; and $54.2 \%(\mathrm{~N}=289)$ are female with a mean age of $47.29(\mathrm{SD}=9.78)$ and median of 48 . All academics work for universities in different countries around the world.

Instruments associated with managing emotions (Trait emotional intelligence questionnaire- short form, TEIQue-SF) and perceived stress scale (PSS) are used in this study and the findings show that there is an invert relationship between perceived stress scale (PSS) and managing emotions; as PSS reduces managing emotions increases. The findings of this study provide a user-friendly summary that can inform and contribute to theory and future research.
\end{abstract}

Keywords: emotional intelligence, teique, managing emotions, pss, academics, universities, well-being.

\section{Introduction.}

The workplace is traditionally considered as being logical, rational and non-emotional with the idea that emotions are irrelevant and the antithesis of rational thinking (Ashforth and Humphrey, 1995; Briner, 1999). However, the work environment is "saturated with emotions" (Ashforth and Humphrey (1995:97) which includes teaching where emotions and emotional intelligence are considered as an integral part of interpersonal interaction (Mortiboys, 2012) and to regard emotions as being antitheses of rationality is too simplistic. with an increase in those working in the service industry, staff are required to be more emotionally engaged with customers and this leads to greater interest being given to emotional intelligence, emotions, and psychology in the work place (Briner, 1999).

A survey carried out for the teaching union- The National Association of Schoolmasters Union of Women TeachersNASUWT (ComRes, 2015) identifies 52\% of teachers seriously considering leaving their job and $47 \%$ seriously considering leaving teaching. Heading the main concerns about the jobs is increased workload, which is identified by $79 \% .87 \%$ of those who respond to the survey feel that they have to work longer hours and $86 \%$ report that their workload had increased over the previous 12 months. 77\% report an increase in work place stress in the last 12 months. Whereas the majority of teachers (68\%) said they enjoyed the work, 69\% of participants report feeling tired and $61 \%$ feeling stressed always or often. The main concern is from the volume of workload (61\%). Kinman (2001) also identifies that a high percentage of those in academic positions would either like to leave the profession or regretted entering the profession in the first place.

Heavy work load is associated with stress and impact upon well-being (for example: Doyle and Hind, 1998; Blix et al, 1994; Cross and Carroll, 1990; Court, 1996; Daniels and Guppy, 1994; Goldenberg and Waddell, 1990; Sliskovic and Sersic, 2011). Other examples of stress experienced on academics include: unmanageable workloads (Early, 1994), Long working hours (Kinman, 1998; Kinman, 2014; Tytherleigh et al, 2005), home/ work life conflict (Winefield et al, 2003).

Kinman et al (2006) comments that those employed as academics are twice as likely as those in the general population of the UK to experience impact upon their psychological health. This is supported by a survey of University teachers 
(Kinman and Jones, 2004) in which it overload of work and work life balance are frequently reported as stressors for university staff and academics that can impact upon work/ life balance (Kinman, 2008).

Work related stress can have a negative impact on a person (Kinman, 2001) and upon others around them. For example, Klenke- Hamel and Mathieu (1990) suggest that academics who feels they experience greater stress than they can cope with are less likely to be involved in student interaction. This can lead to people leaving the teaching profession (Lambert and McCarthy, 2007). Kelly et al (1995) goes as far as to suggest that academics are 50\% more at suicide risk when compared to the average worker.

Aldwin and Park (2004) argue that stress is complex and people respond differently depending on the nature of the experience and how they feel. However, the three main perspectives of stress are constructed around: 1) stimulus based, 2) response based and 3) interactional. Stimulus based is associated with things that cause stress where each person has a tolerance to a particular stress experience and if the stress is too great it may affect his/ her well-being, possibly making them psychology and physically ill (Masuda and Holmes, 1967; Holmes and Rahe, 1967; Bartlett, 1998). The second perspective is "response" based. Rather than "things" causing stress it is the internal reaction/ response to the stress (Selye, 1956). The third perspective is interactional, or "transactional", where a person feels they cannot cope; where there is an imbalance on the demands placed on a person and ability that person has to cope with the demands (Lazarus, 1966, 1991, 2000).

Lazarus (1999) argues that emotion, coping and stress belong together, with emotion being placed as a superordinate because it incorporates coping and stress. Stress is associated with well-being (Hammen, 2005; Schneiderman et al, 2005; Schwabe and Wolf, 2010; Wang, 2005). To help assess how people experience stress Cohen et al (1983) developed an instrument (Perceived Stress Scale- PSS) to assess and evaluate the perceived stress levels. In a study with two samples (332 and 114) of USA college students the findings show that the perceived stress scale (PSS) shows reliability, unaffected by age or gender, and is a good predictor of health (Cohen et al, 1983). For example: they found that the higher the PSS score the higher the smoking rate. A similar study of 508 Turkish university students also shows PSS is a reliable and valid measure of perceived stress (Orucu and Demir, 2009). Similar research has been undertaken using the PSS that shows the PSS having consistent reliability when used in different countries and languages (Cohen et al, 1986; Cohen and Williamson, 1988; Deatherage et al, 2014; Pbert et al, 1992-USA; Hewitt et al, 1992-Canada; Remor, 2006- Spain, Mexico; Mimura and Griffiths, 2004- Japan; Leung et al, 2010; Ng, 2013- China; Wongpakaran and Wongpakaran, 2010- Thailand; Andreou et al, 2011- Greece). Different versions of the PSS have been used (for example: PSS10, PSS14). Cohen and Williamson (1988) explain that the PSS can be used to identify how controllable/ uncontrollable, predictable/ unpredictable, and overloaded a person may feel. This study uses the PSS14 and findings are identified.

Pressman and Cohen (2005) argue that there is a link between emotions and physical/ mental health and that to mismanage negative emotions can cause illness (for example: Alexander and French, 1946; Dunbar, 1954; Friedman, 1990; Gross, 1998) that include: chronic hostility, anger inhibition, heart disease, hypertension (for example: Dembroski et al 1985; Jorgensen et al, 1996; Julkunen, 1994; Suls et al, 1995). Minor ailments can be exacerbated by the inhibition of emotion and that inhibition of emotion could accelerate cancer (Fawzey et al, 1993; Gross, 1989; Pennebaker et al, 1988; Pennebaker, 1990; Spiegel et al, 1989).

Research carried out on emotional intelligence includes that associated with stress, burnout, discrimination, and bullying (Kinman et al, 2006; Lewis, 2004; O’Boyle, 2001; Simpson and Cohen, 2004). Emotional intelligence can also be influential in helping teachers cope with stressful experiences (Nelson et al, 2006; Selva and Loh, 2008). Where research has been carried out it appears to focus mainly on students and the school environment. (For example: Beard et al, 2007). Vandervoort (2006) explains that considering the potential effectiveness of emotional intelligence being included in the secondary school curriculum, (for example: Caplan, et al, 1992; Cohen, 1999) similar results could be expected at the college level. Woods (2010) argues that whereas research has been carried out at school level, little research has been undertaken with academics in higher education. There is, therefore, a clear argument for research to be carried out in this area and to evaluate the concept of emotional intelligence in the higher education context (University) and to investigate the relationship between emotional intelligence and well-being.

Leuner (1966) appears to be the first person to use the term emotional intelligence in a German publication: "Praxis der Kinderpsychologie und Kinderpsychiatrie". Payne (1986) is the first person to use "emotional intelligence" in an English unpublished dissertation. Salovey and Mayer (1990) brought emotional intelligence (ability model) to mainstream academia. However, it became a popular construct following the publication of Goleman's (1995) book titled "Emotional Intelligence: Why It Can Matter More than IQ." Goleman (1995) associates emotional intelligence with a mixture of factors that include mental abilities related to intelligence and emotion as well as personality dispositions and traits. Hence the name given to the model as "mixed". A third model is trait emotional intelligence 
(TEIQue) put forward by Petrides and Furnham (2001).

There appears to be three main models associated with emotional intelligence. These being: ability, mixed and trait. The mixed and trait model relies on self-report while ability emotional intelligence relates to ability and is measured through maximum performance tests (Mayer et al, 2000). Self-report relies on the person being able to accurately assess and evaluate their own emotions. Challenges may be experienced where self-report data and paper pencil tests are imprecise and can carry different meanings (Mayer and Ciarrochi, 2006). However, meta-analysis carried out on self-report are shown to outperform the performance based instruments associated with emotional intelligence by a large margin (for example: Martins et al, 2010; O'Boyle, et al, 2011). Researchers have found that there is a difference in the constructs of performance and self-report (Freudenthaler and Neubauer, 2007; Martins et al, 2010) as they use different approaches to measurement and give different results (Petrides and Furnham, 2001). Cooper and Petrides (2009) add to the critique that whereas other measures, that are self-report, appear to have problems associated with their reliability, the TEIQue demonstrates excellent psychometric properties. As argued by Mayer and Ciarrochi (2006), Petrides and Furnham's (2001) definition of trait requires a non-standard definition of the term trait as the definition of trait includes abilities such as intelligence. To avoid confusion, Petrides and Furnham (2001), therefore, replaces trait emotional intelligence with "Emotional self-efficacy". They regard traits as dispositions, thus distinguishing them from abilities. This may be considered as semantic differences but it is helpful in clarifying the terminology.

The TEIQue is able to predict outcomes much better than other questionnaires (Freudenthaler et al, 2008; Gardner and Qualter, 2009). Cooper and Petrides (2009) argue that the TEIQue covers each factor in the trait emotional intelligence sampling domain whereas other questionnaires may exclude factors associated with trait emotional intelligence. Petrides and Furnham (2001) add that trait emotional intelligence can be concerned with behaviours and also subjective judgements. Trait emotional intelligence appears to be a strong predictor of well-being and mental health (for example: Dawda and Hart, 2000; Johnson et al, 2009; Petrides, 2011; Russo et al, 2012; Saklofske et al, 2003). The findings, therefore, suggest that trait emotional intelligence (TEIQue) is a suitable instrument to use in research.

This study uses trait emotional intelligence (TEIQue) that Petrides (2011:657) defines as a "constellation of self-perceptions that are located at lower levels of personality hierarchy" (for example: assertiveness, empathy). Petrides (2009b) adds that trait emotional intelligence incorporates self-perceived abilities via a personality framework that identifies items that include behavioural dispositions and self-perceived abilities, that can be measured through a self-report. Petrides and Furnham (2001) links trait emotional intelligence with the personality "big 5" where there is an overlap between trait emotional intelligence and the "big 5" personality dimensions (Costa and McCrae, 1992).

\section{Methodology}

\subsection{Instruments used}

The sample size and demographic data is analysed and, before testing is carried out, screening is undertaken and data examined, including: outliers, range, means (average score), missing values, and normality. The instruments used in this study are: managing emotions (Petrides, 2009a), and perceived stress scale- PSS (Cohen et al, 1983).

Managing emotions: Petrides (2009a). (Version 1.50- TEIQue-SF). Petrides and Furnham (2001) advise that the TEIQue is constructed to provide comprehensive coverage of the trait domain. The short thirty item questionnaire, used in this study, is based upon the long questionnaire of the TEIQue (Petrides and Furnham, 2003). It assesses how participants (academics) manage their emotions and is designed to assess global trait emotional intelligence.

Perceived stress scale: Cohen et al (1983). The perceived Stress Scale (PSS14) assesses the global measure of perceived stress and asks participants about their thoughts and feelings about their life and job, over the previous month. The higher the score the greater the person's perception is of how stressful their life is. The P.S.S.14 is a self-report questionnaire/ survey that is designed to measure psychological stress over the previous month.

\subsection{Procedure}

In excess of 3,900 potential participants are directed, via LinkedIn, to the online questionnaire/ survey which remains open between the 16th October and the 4th December 2014. Participants are asked how they manage emotions (TEIQue-SF) and how they perceive stress (PSS14).

Checks are made on missing data, outliers, duplicates and normality. Internal consistency is assessed, including Cronbach's alpha, to find out the degree that items within scales measure the same attribute. Correlation is undertaken using Pearson (parametric test) product- moment correlation.

\subsection{Participants}

Of the 543 people who respond $6(1.10 \%)$ advise that they are students and $4(0.74 \%)$ hold administrative roles at University; a total of 10 people $(1.84 \%)$. To avoid confusion and to misinterpret data, the information uploaded by the 
aforementioned 10 people are removed from the data. Therefore, the sample includes 533 academics from universities around the world: $100 \%(\mathrm{~N}=533) ; 45.8 \%(\mathrm{~N}=244)$ male, with a mean age of $48.78(\mathrm{SD}=10.9)$; and $54.2 \%(\mathrm{~N}=289)$ female, with a mean age of $47.29(\mathrm{SD}=9.78)$.

\section{Results and Discussion}

\subsection{Internal consistency}

Data is analysed using SPSS (Statistical package for the social sciences). Checks on internal consistency are undertaken using Cronbach's alpha coefficient (reliability of scales). In this study Cronbach alpha, for managing emotions, is 0.88 and for PSS, Cronbach alpha is 0.81 suggesting good internal consistency.

Standard deviation is calculated showing how spread out the sample is and how far it deviates from the mean. The findings show: Managing emotions (Petrides, 2009a) SD = 1.58; and PSS (Cohen et al, 1983) SD = 7.61.

Skewness and kurtosis is analysed where normal distribution, values of skewness and kurtosis, equal to 0 . Skewness identifies the symmetry of distribution. For example if there is normal distribution the skewness is 0 . Standard error is also reported which estimates how far the data is either side of the mean. Table 1 provides a summary of findings from skew, kurtosis, standard error and normal distribution (z).

Table 1. Skewness and kurtosis variables

\begin{tabular}{cccccccc}
\hline No & Variable & Skew. & Std error & Z skew. & Kurt. & Std error & Z Kurt. \\
\hline 1 & $\begin{array}{c}\text { Managing emotions } \\
\text { (Petrides, 2009) }\end{array}$ & -0.51 & 0.11 & -4.64 & 0.57 & 0.22 & 2.59 \\
2 & $\begin{array}{c}\text { PSS (Cohen et al, } \\
1983)\end{array}$ & 0.23 & 0.11 & 2.10 & -0.45 & 0.21 & 2.14 \\
& & & & & & \\
\end{tabular}

The findings show a small negative skew (skew to the left) for managing emotions and a small positive skew (skew to the right) is shown for PSS14. Where skewness has a positive value it shows a higher number of scores on the left hand side of the distribution (For example PSS: 0.23) where participants are more inclined to score lower levels. A negative value of skewness (for example managing emotions: -0.51) shows a greater number to the right where participants are more likely to score higher levels.

The findings also show that there is small negative kurtosis for stress/ coping, PSS and emotional demands. A slightly larger positive kurtosis is shown for managing emotions and home/ work recovery. The findings are within the recommended parameters of -1.5 to +1.5 (Tabachnick and Fidell, 2013).

The standard error indicates the reliability, or accuracy of the mean values between samples. In this study, the skew standard error suggests $95 \%$ confidence in the sample mean being $0.11(11 \%)$ or $0.12(12 \%)$ from the mean. These are considered to be reasonable. The kurtosis standard error is shown to range between $0.21(21 \%)$ and 0.23 (23\%). The findings are expected as the sample is based upon diverse responses from people.

To assess normal distribution, $\mathrm{Z}$ values are calculated dividing the skew and kurtosis figures by their respective standard error. The $Z$ values are shown in table 1 ranging from -4.64 to +2.59 . Mayers (2013) recommends that $\mathrm{z}$ scores should not be greater than plus or minus 1.96. If this does occur then it suggests normal distribution is compromised. However, Pallant (2013) explains, scores are often unevenly distributed, in particular with research in social science. In this study, the sample size is 533 if the sample sizes are large enough (for example: 30 or more) the violation of normality should not cause a problem (Pallant, 2013).

\subsection{Correlation}

Internal correlation is undertaken on managing emotions. In this study, Cronbach's alpha is calculated on each of the items in managing emotions (TEIQue). Overall Cronbach's alpha is shown to be 0.88 , over the 30 items in the scale. Mouton et al (2013) uses the TEIQue on a sample of physical education teachers. The findings show Cronbach alpha to be 0.94 . Vesely et al's (2014) study on teachers find Cronbach alpha to be 0.88 . In a study undertaken by Swami et al (2013) Cronbach alpha is shown to be 0.76 . The findings from this study (0.88) therefore suggest good internal consistency.

Internal correlation is also undertaken on PSS and Cronbach alpha calculated on each of the 14 items. Overall Cronbach's alpha is shown to be 0.81 . Cohen et al (1983) carries out a study of 960 males and 1,427 females. The findings show Cronbach alpha to be 0.78. Cohen and Janicki-Deverts (2012) report on findings of a questionnaire/ survey undertaken in 2006 and 2009. The findings show Cronbach Alpha to be 0.91 for both 2006 and 2009. Siegling et al (2015) report Cronbach alpha to be 0.87. Swami et al (2013) reports Cronbach alpha to be 0.70 . The findings from this study (0.81) show reasonable comparisons with the examples of earlier research suggesting good internal consistency. 
Correlation is undertaken using Pearson (parametric test) product- moment correlation on managing emotions and PSS. The correlation coefficient $(r)$ indicates the strength of relationships between variables. The findings from this study show that $r=-0.52$ indicating that there is a significant negative relationship between managing emotions and PSS. Siegling et al (2015) find a -0.60 correlation between PSS and managing emotions (TEIQue). In a study undertaken by Swami et al (2013) on a sample of resident doctors correlation between PSS and managing emotions (TEIQue) is -0.59 . These are examples, however, the findings suggest that there is consistency across studies but further research is recommended as undertaking social science research may result in different findings from other samples.

The shared variance, in this study shows that where $r=-0.52, r 2=27 \%$. This suggests that there is an invert relationship between PSS and managing emotions. The greater the perceived stress (PSS) the person experiences the less they manage emotions. However the premise of this finding is that there may be a cause/ effect between managing emotions and perceived stress. Whereas the statistical findings may suggest a relationship, it does not necessarily follow that one causes the other. The findings acknowledge Bassey's (1999) argument that predictions associated with social science can give rise to fuzzy generalisations. Firm/ conclusive links and relationships cannot necessarily be made. However the findings do help to contribute to theory from which fuzzy generalisations can be made (Bassey 2010).

The findings are interesting and significant adding to the research. It does identify the challenges of undertaking social science research as interpretations of findings can lead to possibly misleading conclusions and fuzzy generalisation.

\section{References}

Aldwin, C. M., \& Park, C. L. (2004). Coping and physical health outcomes: an overview. Psychology and Health, 19, 277-281. http://dx.doi.org/10.1080/0887044042000193514

Alexander, F., \& French, T. M. (1946). Psychoanalytic therapy: Principles and applications. New York: Ronald Press.

Andreou, E., Alexopoulos, E. C., Lionis, C., Varvogli, L., Gnardellis, C., Chrousos, G. P., \& Darviri, C. (2011). Perceived Stress Scale: Reliability and validity study in Greece. International Journal of Environmental Research and Public Health, 8(8), 3287-3298. http://dx.doi.org/10.3390/ijerph8083287.

Ashforth, B. E., \& Humphrey, R. E. (1995). Emotion in the workplace. A reappraisal. Human Relations, 48, 97-124. http://dx.doi.org/10.1177/001872679504800201.

Bartlett, D. (1998) Stress: Perspectives and processes. London: Open University Press.

Bassey, M. (1999). Case study research in educational settings. Buckingham and Philadelphia: Open University Press.

Bassey, M. (2001). A solution to the problem of generalisation in educational research: Fuzzy prediction. Oxford Review of Education, 27(1), 5-22. http://dx.doi.org/10.1080/03054980123773.

Beard, C., Clegg, S., \& Smith, K. (2007). Acknowledging the affective in higher education. British Educational Research Journal, 33(2), 235-252. http://dx.doi.org/10.1080/01411920701208415.

Blix, A. G., Cruise, R. J., Mitchell, B. M., \& Blix G. G. (1994). Occupational stress among university teachers. Educational Research, 36, 157-169. http://dx.doi.org/10.1080/0013188940360205.

Briner, R. B. (1999). The neglect and importance of emotion at work. European Journal of Work and Organisational Psychology, 8(3), 323-346. http://dx.doi.org/10.1080/135943299398212.

Caplan, M., Weissberg, R. P., Grober, J. S., Sivo, J., Grady, K., \& Jacoby C. (1992). Social competence program with inner city and suburban young adolescents; Effects of social adjustment and alcohol use. Journal of Consulting and Clinical Psychology, 60, 53-63. http://PMID:1556286

Cohen, J. (1999). Educating minds and hearts: Social emotional learning and the passage into adolescence. New York: Teachers College Press.

Cohen, S., \& Janicki-Deverts, D. (2012). Who's stressed? Distributions of psychological stress in the United States in probability samples from 1983, 2006, and 2009. Journal of Applied Social Psychology, 42(6), 1320-1334. http://dx.doi.org/10.1111/j.1559-1816.2012.00900.x

Cohen, S., \& Williamson, G. (1988). Perceived stress in a probability sample of the United States. In: S. Pacapan, and S. Oskamp (Eds.) The social psychology of health: Claremont symposium on applied social psychology. Newbury Park. CA: Sage, 31-67.

Cohen, S., Kamarck, T., \& Mermelstein, R. (1983). A global measure of perceived stress. Journal of Health and Social Behaviour, 24, 385-396. http://dx.doi.org/10.2307/2136404.

Cohen, S., Sherrod, D. R., \& Clark, M.S. (1986). Social skills and the stress protective role of social support. Journal of Personality and Social Psychology, 50, 963-973. http://dx.doi.org/10.1037/0022-3514.50.5.963. 
ComRes (2015) Teachers' satisfaction and wellbeing in the work place: NASUWT. The Teacher's Union. http://www.nasuwt.org.uk/consum/groups/public/@press/documents/nas_download/nasuwt_011847.pdf.

Cooper, A., \& Petrides, K. V. (2009). A psychometric analysis of the trait emotional intelligence questionnaire short form (TEIQue-SF) using item response theory. Journal of Personality Assessment, 92(5), 449-457. http://dx.doi.org/10.1080/00223891.2010.497426

Costa, P. T. Jr., \& McCrae, R. R. (1992). Normal personality assessment in clinical practice: The NEO Personality Inventory. Psychological Assessment, 4(1), 5-13. http://dx.doi.org/10.1037/1040-3590.4.1.5.

Court, S. (1996). The use of time by academic and related staff. Higher Education Quarterly, 50, 237-260. 237-260. http://dx.doi.org/10.1111/j.1468-2273.1996.tb01705.x

Cross, G., \& Carroll, D. (1990). Goodwill under stress: Morale in UK universities. London: Association of University Teachers.

Daniels, K., \& Guppy, A. (1994). An exploratory study of stress in British University. Higher Education Quarterly, 48, 135-144. http://dx.doi.org/10.1111/j.1468-2273.1994.tb01646.x

Dawda, D., \& Hart, S. D. (2000). Assessing emotional intelligence: reliability and validity of the Bar-On Emotional Quotient-Inventory (EQ-i) in university students. Personality and Individual Differences, 28, 797-812. http://dx.doi.org/10.1016/S0191-8869(99)00139-7

Deatherage, S., Servaty-Seib, H. L., \& Aksoz, I. (2014). Stress, coping and internet use of college students. Journal of American College Health, 62(1), 40-46. http://dx.doi.org/10.1080/07448481.2013.843536.

Dembroski, T. M., MacDougall, J. M., Williams, R. B., Haney, T. L., \& Blumenthal, J. A. (1985). Components of type A hostility and anger-in: Relationship to angiographic findings. Psychosomatic Medicine, 47, 219-233. http://PMID:4001281

Doyle, C., \& Hind, P. (1998). Occupational stress, burnout and job status in female academics. Gender, work and organisations, 5, 67-68. http://dx.doi.org/10.1111/1468-0432.00047

Dunbar, F. (1954). Emotions and bodily changes. New York: Columbia University Press.

Early, P. (1994). Lecturers' work load and factors affecting stress levels. Slough: NFER.

Fawzey, F., Fawzey, N., Hyun, C., Elashoff, R., Gulthries, D., Fahey, J., \& Morton D. (1993). Malignant melanoma: Effects of an early structured psychiatric intervention, coping and affective state on recurrence and survival 6 years later. Archives of General Psychiatry, 50, 681-689. http://dx.doi.org/10.1001/archpsyc.1993.01820210015002.

Freudenthaler, H. H., \& Neubauer, A. C. (2007). Measuring emotional management abilities: Further evidence of the importance to distinguish between typical and maximum performance. Personality and Individual Differences, 29, 105-115. http://dx.doi.org/10.1016/j.paid.2006.10.031.

Freudenthaler, H. H., Nebauer, A. C., Gabler, P. Scherl, W. G., \& Rindermann, H. (2008). Testing the Trait Emotional Intelligence Questionnaire (TEIQue) in a German speaking sample. Personality and Individual Differences, 45, 673-678. http://dx.doi.org/10.1016/j.paid.2008.07.014

Friedman, H. S. (1990). Personality and disease. New York: Wiley.

Gardner, K., \& Qualter, P. (2009). Emotional Intelligence and Borderline personality disorder. Personality and Individual Differences, 47, 94-98. http://dx.doi.org/10.101016/j.paid.2009.02.004

Goldenberg, G. D., \& Waddell, J. (1990). Occupational stress and coping strategies amongst female baccalaureate nursing teachers. Journal of Advances in Nursing, 15, 531-543. http://dx.doi.org/10.1111/j.1365-2648.1990.tb01852.x

Goleman. D. (1995). Emotional Intelligence: Why It Can Matter More than IQ. Bantam Books, New York. NY.

Gross, J. (1989). Emotional expression in cancer onset and progression. Social Science and Medicine, 28, 239-1248. http://dx.doi:10.1016/0277-9536(89)90342-0

Gross, J. J. (1998). The Emerging Field of Emotion Regulation: An Integrative Review. Review of General Psychology, 2(3), 271-299. http://dx.doi.org/10.1037/1089-2680.2.3.271.

Hammen, C. (2005). Stress and depression. Annual Review of Clinical Psychology, 1, 293-319. http://PMID: 17716090

Hewitt, P. L., Flett, G. L., \& Mosher, S. W. (1992). The perceived stress scale: Factor structure and relation to depression symptoms in a psychiatric sample. Journal of Psychological and Behavioural Assessment, 14, 247-257. http://dx.doi.org/10.1007/BF00962631 
Holmes, T. H., \& Rahe, R. H. (1967). The social readjustment rating scale. Journal of Psychosomatic Research, 11, 213-218. http://dx.doi.org/10.1016/0022-3999(67)90010-4

Johnson, S. J., Batey, M., \& Holdsworth, L. (2009). Personality and health: The mediating role of trait emotional intelligence and work locus of control. Personality and Individual Differences, 47, 470-475. http://dx.doi.org/10.1016/j.paid.2009.04.025.

Jorgensen, R. S., Johnson, B. T., Kolodziej, M. E., \& Schreer, G. E. (1996). Elevated blood pressure and personality: A meat analytic review. Psychological Bulletin, 120, 293-320. http://PMID:8831299

Julkunen, J., Salonen, R., Kaplan, G. A., Chesney, M. A., \& Salonen, J. T. (1994). Hostility and the progression of carotid atherosclerosis. Psychosomatic Medicine, 56, 519-525. http://PMID:7871107

Kelly, S., Charlton, J., \& Jenkins, R. (1995) Suicide deaths in England and Wales (1982-92). The contribution of occupation and geography. Population trends, 80, 16-25. http://PMID:7664129

Kinman, G. (2014). Doing more with less? Work and wellbeing in academics. Somatechnics, 4(2), $219-235$. http://dx.doi.org/10.3366/soma.2014.0129

Kinman, G. (1998). Pressure points: A survey into the causes and consequences of occupational stress in UK academic and related staff. London: Association of University Teachers. https://www.researchgate.net/profile/Gail_Kinman/publication/266473393_Pressure_Points_A_survey_into_the_c auses_and_consequences_of_occupational_stress_in_UK_academic_and_related_staff/links/551be18a0cf $2 \mathrm{fe} 6 \mathrm{cbf} 7$ 5f764.pdf

Kinman, G. (2001). Pressure Points: A review of research on stressors and strains in UK academics. Educational Psychology, 21(4), 473-492. http://dx.doi.org/10.1080/01443410120090849

Kinman, G. (2008). Work stressors, health and sense of cohesion in UK academic employees. Educational Psychology, 28(7), 823-835. http://dx.doi.org/10.1080/01443410802366298

Kinman, G., \& Jones, F. (2004). Working to the limit: Stress and work-life balance in academic related employees in the UK. The Higher Education Union. (Aut). Association of University Teachers. http://www.ucu.org.uk/media/700/Working-to-the-limit-.pdf/pdf/workingtothelimit.pdf

Kinman, G., Jones, F., \& Kinman, R. (2006). The well-being of the UK academy. 1998-2004. Quality in higher education, 12(1), 15-27. http://dx.doi.org/10.1080/13538320600685081

Klenke- Hamel, K. E., \& Mathieu, J. E. (1990). Role strains, tension, and job satisfaction influences on employees propensity to leave: A multi sample replication and extension. Human Relations. 43, 791-807. http://dx.doi.org/10.1177/001872679004300806

Lambert, R., \& McCarthy, C. (Eds.) (2007). Understanding Teacher Stress in an Age of Accountability. Information Age Publishing: Charlotte.

Lazarus R. S. (1991). Emotion and adaption. Oxford: Oxford University Press.

Lazarus, R. S. (1966). Psychological stress and the coping process. New York: McGraw-Hill.

Lazarus, R. S. (1999). Stress and Emotion: A new Synthesis. Springer Publishing Company, Inc.

Lazarus, R. S. (2000). Towards better research on stress and coping. American Psychologist, 55(6), 665-673. http://dx.doi.org/10.1037/0003-066X.55.6.665

Leuner, B. (1966). Emotionale Intelligenz und Emanzipation (Emotional intelligence and emancipation). Praxis der Kinderpsychologie und Kinderpsychiatry, 15, 196-203.

Leung, D. Y., Lam, T., \& Chan, S. S. (2010). Three versions of perceived stress scale: validation in a sample of Chinese cardiac patients who smoke. BioMed Central Public Health, 10, 513. http://dx.doi.org/10.1186/1471-2458-10-513

Lewis, D. (2004). Bullying at work: The impact of shame among university and college academics. British Journal of Guidance and Counseling, 32(3), 281-299. http://dx.doi.org/10.1080/03069880410001723521

Martins, A., Ramalho, N., \& Morin, E. (2010). A comprehensive Meta-analysis of the relationship between emotional intelligence and health. Personality and Individual Differences, 49, 554-564. http://dx.doi.org/10.1016/j.paid.2010.05.029

Masuda, M., \& Holmes, T. H. (1967). Magnitude estimations of social readjustments. Journal of Psychosomatic Research, 11, 219-225. http://dx.doi.org/10.1016/0022-3999(67)90011-

Mayer, J. D., \& Ciarrochi, J. (2006). Clarifying concepts related to emotional intelligence: A proposed glossary, In J. 
Ciarrochi, J., Forgas, J., \& Mayer, J. D. (Eds.) Emotional Intelligence in Everyday life (2nd ed). Psychology Press, Inc, 261-267.

Mayer, J. D., Salovey, P., \& Caruso, D. (2000). Emotional intelligence. In: R. Sternberg. Handbook of intelligence. Cambridge, UK. Cambridge University Press, 528-549.

Mayers, A. (2013). Introduction to statistical and SPSS in psychology. Pearson.

Mimura, C. \& Griffiths, P. (2004). A Japanese version of the perceived stress scale: Translation and preliminary test. International Journal of Nursing Studies, 41, 379-385. http://dx.doi.org/10.1016/j.ijnurstu.2003.10.009

Mortiboys, A. (2012). Teaching with emotional intelligence: A step by step guide for higher and further education professionals (2nd ed). Routledge.

Mouton, A., Hansenne, M. Delcour, R., \& Cloes, M. (2013). Emotional intelligence and self-efficacy among physical education teachers. Journal of Teaching in Physical Education, 32, 342-354. https://orbi.ulg.ac.be/bitstream/2268/157729/1/Mouton\%20et\%20al\%202013\%20JTPE.pdf

Nelson, D. B., Low, G. R., \& Nelson, K. (2006). The emotionally intelligent teacher: A transformative. Institute for Emotional Intelligence. http://www.tamuk.edu/edu/kwei000/Research/Articles/Article_files/Emotionally_Intelligent_Teacher.pdf.

$\mathrm{Ng}$, S. (2013). Validation of the 10 item Chinese perceived stress scale in elderly service workers: one factor verses two factor structure. BMC Psychology, 1(1), 1-9. http://dx.doi.org/10.1186/2050-7283-1-9.

O’Boyle, E. H., Humphrey, R. H., Pollack, J. M., Hawver, H., \& Story, P. A. (2011). The relation between emotional intelligence and job performance. A meta-analysis. Journal of Organisational Behaviour, 32(5), 788-818.http://dx.doi.org/10.1002/job.714

O'Boyle, E. J. (2001). Salary compression and inversion in the University workplace. International Journal of Social Economics, 28(10-12), 959-979. http://dx.doi.org/10.1108/03068290110404679

Orucu, M. C., \& Demir, A. (2009). Psychometric evaluation of perceived stress scale for Turkish university students. Stress and Health, 25, 103-109.http://dx.doi.org/10.1002/smi.1218

Pallant, J. (2013). SPSS survival manual: A step by step guide to data analysis using IBM SPSS (5th ed). McGraw Hill.

Payne, W. L. (1986). A study of emotion: Developing Emotional Intelligence; Self-Integration, Relating to fear, Pain and Desire. Disertations Abstracts International. The Union for Experimenting Colleges and Universities. http://eqi.org/payne.htm.

Pbert, L., Doefler, L. A., \& DeCosimo, D. (1992). An evaluation of the perceived stress scale in two clinical populations. Journal of Psychopathology and Behavioural Assessment, 14, 363-375. http://dx.doi.org/10.1007/BF00960780

Pennebaker, J. W. (1990). Opening up: The healing powers of confiding in others. New York: Morrow

Pennebaker, J. W., Kiecolt-Glaser, J. K., \& Glaser, R. (1988). Disclosure of traumas and immune function: Health implications for psychotherapy. Journal of Consulting and Clinical Psychology, 56(2), 239-245. http://dx.doi.org/10.1037/0022-006X.56.2.239

Petrides, K. V. (2009a). Technical manual for the trait emotional intelligence questionnaire (TEIQue). London, England: London Psychometric Laboratory. http://www.psychometriclab.com/Default.aspx?Content=Links\&id=19

Petrides, K. V. (2009b). Psychometric properties of the Trait Emotional Intelligence Questionnaire. In: C. Stough, D. H. Saklofske, and J. D. Parker, Advances in the assessment of emotional intelligence. New York: Springer. http://dx.doi.org/DOI: 10.1007/978-0-387-88370-0_5

Petrides, K. V. (2011). Ability and trait emotional intelligence. In: T. Chamorro- Premuzic, A. Furnham, \& S. von Stumm (Eds.), The Blackwell-Wiley handbook of individual differences, New York: Wiley.

Petrides, K. V., \& Furnham, A. (2001). Trait emotional intelligence: Psychometric investigation with reference to established trait taxonomies. European Journal of Personality, 15(6), 425-448. http://dx.doi.org/10.1002/per.416

Pressman, S. D., \& Cohen, S. (2005). Does positive affect influence health? Psychological Bulletin, 131, 925-971. http://dx.doi.org/doi:10.1037/0033-2909.131.6.925

Remor, E. (2006). Psychometric properties of the European Spain version of the perceived stress scale 9 PSS). The Spanish Journal of Psychology, 9, 86-93. http://dx.doi.org/10.1017/S1138741600006004

Russo, P. M., Mancini, G., Trombini, E., Baldaro, B., Mavroveli, S., \& Petrides, K. V. (2012). Trait Emotional Intelligence and the Big Five: A study on Italian Children and Preadolescents. Journal of Psychoeducational 
Assessment, 30, 274-283. http://dx.doi.org/10.1177/0734282911426412

Saklofske, D. H., Austin, E. J., \& Minski, P. S. (2003). Factor structure and validity of a trait emotional intelligence measure. Personality and Individual differences, 34(2), 707-721. http://dx.doi.org/10.1177/0829573511406510

Salovey, P., \& Mayer, J. D. (1990). Emotional Intelligence. Imagination, Cognition and Personality, 9, 185-211. http://dx.doi.org/10.2190/dugg-p24e-52wk-6cdg

Schneiderman, N., Ironson, G., \& Siegel, S. D. (2005). Stress and health: Psychological, behavioural and biological determinants. Annual Review of Clinical Psychology, 1, 607-628. http://dx.doi.org/10.1146/annurev.clinpsy.1.102803.144141

Schwabe, L., \& Wolfe, O. T. (2010). Learning under stress impairs memory formation. Neurobiology of Learning and Memory, 93(2), 183 -188. http://dx.doi.org/10.1016/j.nlm.2009.09.009

Selva, R. S., \& Loh, S. C. (2008). Emotional intelligence of science and mathematics teachers: A Malaysian experience. Journal of Science and Mathematics, 31(2), 132-163. http:// EJ848972. http://www.recsam.edu.my/R\&D_Journals/YEAR2008/dec2008vol2/emotional(132-163).pdf

Selye, H. (1956). The Stress of Life. London, Longmans, Green and Co.

Siegling, A. B., Furnham, A. \& Petrides, K. V. (2014). Trait emotional intelligence and personality: Gender-invariant linkages across different measures of the Big Five. Journal of Psychoeducational Assessment, 33, 57-67. http://dx.doi.org/10.1177/0734282914550385 jpa.sagepub.com

Siegling, A. B., Vesely, A. K., Petrides, K. V., \& Saklofske, D. H. (2015). Incremental validity of the trait emotional intelligence questionnaire- short form (TEIQue-SF). Journal of Personality Assessment, 97(5), 525-535. http://dx.doi.org/10.1080/00223891.2015.1013219

Simpson, R., \& Cohen, C. (2004). Dangerous work: The gendered nature of bullying in the context of higher education. Gender Work and Organisation, 11(2), 163-186. http://dx.doi.org/10.1111/j.1468-0432.2004.00227.x

Sliskovic, A., \& Sersic, D. M. (2011). Work stress among university teachers: gender and position differences. Arh Hig Rada Toksikol, 62, 299-307. http://dx.doi.org/10.2478/10004-1254-62-2011-2135

Spiegel, D., Bloom, J. R., Kraemer, H. C., \& Gottheil, E. (1989). Effect of psychosocial treatment on survival of patients with metastatic breast cancer. The Lancet, 2, 888-891. http://dx.doi.org/2571815

Suls, J., Wan, C. K., \& Costa, P. T. Jr. (1995). Relationship of trait anger to resting blood pressure: A meta-analysis. Health Psychology, 14, 444-456. http://dx.doi.org/10.1037/0278-

Swami, M. K., Mathur, B. K., \& Puship, B. K. (2013). Emotional intelligence, perceived stress and burnout among resident doctors: An assessment of the relationship. The National Medical Journal of India, 26(4). 210-213, PMCID: PMC24758443

Tytherleigh, M. Y., Webb, C., Copper, C. L., \& Ricketts C. (2005). Occupational stress in UK higher education institutions: a comparative study of all staff categories. Higher Education Research and Development, 24(1), 41-61. http://dx.doi.org/10.1080/0729436052000318569

Vesely, A. K., Saklofske, D. H., \& Nordstokke, D. W. (2014). EI training and preservice teacher well-being. Personality and Individual Differences, 65, 81-85. http://dx.doi.org/10.1016/j.paid.2014.01.052 0191-8869/ 2014

Wang, J. (2005). Work stress as a risk factor for major depressive episode(s). Psychological Medicine, 35, 865-871. http://dx.doi.org/10.1017/S0033291704003241

Winefield, A. H., Gillespie, N. A., Stough, C., Dua, J., Hapuarachchi, J., \& Boyd, C. (2003). Occupational stress in Australian university staff: Results from a national survey. International Journal of Stress Management, 10, 51-63.

Wongpakaran, N., \& Wongpakaran, T. (2010). The Thai version of the PSS-10: an investigation of its psychometric properties. Bio Psycho Social Medicine, 4(6), 1-6. http://dx.doi.org/10.1186/1751-0759-4-6

Woods, C. (2010). Employee wellbeing in the higher education workplace: a role for emotion scholarship. Higher Education, 60, 171-185. http://dx.doi.org/10.1007/s10734-009-9293-y

\section{(cc) $\mathrm{Br}$}

This work is licensed under a Creative Commons Attribution 3.0 License. 